\title{
Małgorzata NIEWIADOMSKA-CUDAK
}

\author{
Warszawa
}

\section{Frekwencja wyborcza w elekcjach samorządowych w Polsce}

$\mathbf{S}^{3}$ ynonimem demokracji w większości współczesnych systemów politycznych stały się wolne wybory. Traktuje się je jako sposób obsadzania urzędu lub stanowiska za pomocą decyzji podejmowanych przez elektorat ${ }^{1}$. Ich cykliczność i rywalizacyjność przesądza o demokratyzmie systemu politycznego ${ }^{2}$. Elekcje odbywają się więc regularnie, w ramach terminów określonych w ustawie zasadniczej. Jednym z konstytucyjnych praw politycznych polskich obywateli staje się prawo wyborcze ${ }^{3}$. Wprowadzenie w demokratycznych systemach politycznych zasady powszechnego prawa wyborczego przyczyniło się do postrzegania wyborów jako ważnego elementu w procesie socjalizacji obywateli. Czynne prawo wyborcze w Rzeczypospolitej Polskiej opiera się na zasadach powszechności, równości, bezpośredniości, proporcjonalności i tajności głosowania ${ }^{4}$.

Wybory do rad gmin są powszechne, równe, bezpośrednie, odbywają się w tajnym głosowaniu. Różnica polega na tym, że w gminach do 20000 mieszkańców wybory przeprowadzane są według formuły większościowej, natomiast w większych liczących powyżej 20000 mieszkańców podział mandatów dokonuje się według formuły proporcjonalnej ${ }^{5}$. Co istotne, kandydatów na radnych mogą zgłaszać partie polityczne, stowarzyszenia oraz organizacje społeczne i wyborcy. Wynika z tego, że krag podmiotów uprawnionych do zgłaszania kandydatów do rad jest szerszy niż w wyborach parlamentarnych, gdzie przede wszystkim uprawnienia takie posiadają partie polityczne ${ }^{6}$.

${ }^{1}$ A. Heywood, Politologia, Warszawa 2006, s. 285.

2 Za sprawą J. Schumpetera przyjęto, iż linią graniczną oddzielającą ustroje demokratyczne od niedemokratycznych są cykliczne i rywalizacyjne wybory. Zob. J. Schumpter, Kapitalizm, socjalizm, demokracja, Warszawa 1995, s. 341 .

${ }^{3}$ Termin ten funkcjonuje w dwóch znaczeniach: podmiotowym i przedmiotowym. W tym pierwszym jest prawem stricte obywatelskim, tzn. przysługującym wyłącznie osobom posiadającym obywatelstwo polskie. Jest wyrazem ich pośredniego sprawowania władzy poprzez posłów, senatorów, Prezydenta Rzeczypospolitej Polskiej i przedstawicieli do organów samorządu terytorialnego. Mamy czynne i bierne prawo wyborcze. To pierwsze jest uprawnieniem do dokonania aktu wyborczego, zaś drugie możnością uzyskania wyboru. Natomiast prawo wyborcze w znaczeniu przedmiotowym odnosi się do zbioru norm prawnych regulujących zasady i tryb przeprowadzania wyborów do organów przedstawicielskich oraz wyboru Prezydenta. Zob. T. Bulenda, Encyklopedia wiedzy politycznej, pod red. M. Chmaja, J. Marszałek-Kawy, W. Sokoła, Toruń 2005, s. 283.

4 Ibidem, s. 283.

${ }^{5}$ Bezpośredniość wyborów do organów samorządowych polega na tym, że wyborca wybiera radnych bezpośrednio spośród kandydatów zgłoszonych w okręgach wyborczych. Liczbę radnych wybieranych do rad ustala wojewoda odrębnie dla każdej rady, po porozumieniu z komisarzem wyborczym. Ustalenie ilości radnych dla każdej rady następuje na podstawie liczby mieszkańców zamieszkałych na obszarze działania danej rady. Obwody głosowania powinny liczyć od 500 do 3000 mieszkańców. Do wyboru rady w gminach liczących do 20000 mieszkańców wybiera się w okręgach od 1 do 5 radnych, a powyżej 20000 tworzy się okręgi wyborcze, w których wybiera się od 5 do 8 radnych. Natomiast podział na okręgi, ich granice i numery oraz liczbę radnych w każdym okręgu ustala na wniosek wójta, burmistrza, prezydenta miasta, rada gminy. Zob. szerzej M. Chmaj, Encyklopedia wiedzy..., op. cit., s. 445.

${ }^{6}$ Zob. ibidem, s. 445. 
Społeczeństwo od czasu wprowadzenia w Polsce wolnych wyborów do organów parlamentarnych i samorządowych mogło w akcie głosowania wypowiedzieć się o swoich preferencjach politycznych, a także mieć wpływ na to, kto będzie sprawował władzę w kraju i w jednostkach samorządu terytorialnego. Lokalni obywatele uzyskali prawo oceny władzy poprzez jej akceptację lub dezaprobatę w kolejnym akcie głosowania, a co za tym idzie wpływu na przeobrażenia polityczne na ich macierzystym terenie. Świadomość istoty ważności wyborów parlamentarnych i samorządowych oraz współodpowiedzialności lokalnych środowisk za zachodzące przeobrażenia wzrasta w Polsce wraz z rozwojem procesu demokratyzacji życia społecznego, czego efektem staje się nieco wzrastająca frekwencja wyborcza, przynajmniej w ostatniej elekcji parlamentarnej w 2007 r. i samorządowej w 2006 r.

Zagadnienia zawarte w tej publikacji będą więc koncentrować się na frekwencji wyborczej w wyborach samorządowych w Polsce, ze szczególnym omówieniem frekwencji w mieście na prawach powiatu, jakim jest Łódź. Aglomeracja ta bowiem jest nie tylko interesująca ze względu na swoje położenie, ale także dzięki przeobrażeniom kulturowym i ekonomicznym, jakie w niej zaszły w ostatnim okresie. Z typowej robotniczej osady Łódź stała się miastem czterech kultur - niemieckiej, żydowskiej, rosyjskiej i polskiej oraz prężnie prosperującym ośrodkiem akademickim. Ponieważ na frekwencję wyborczą mają wpływ między innymi czynniki społeczno-demograficzne, takie jak wykształcenie, dochód oraz pozycja zawodowa, warto więc zobrazować, jak kształtuje się ona w aglomeracji, gdzie społeczeństwo przechodzące etapy rozwoju od typowo robotniczych domostw zaczyna podążać za wiedzą i przebranżawiać się z przemysłu typowo włókienniczego w kierunku nowoczesnych technologii.

W wyborach samorządowych odbywających się od 1990 r. frekwencja wyborcza, w ciagu odbytych pięciu elekcji, przedstawiała się następująco:

\begin{tabular}{|c|c|}
\hline Wybory & Frekwencja w \% \\
\hline 1990 & 42,3 \\
\hline 1994 & 33,8 \\
\hline 1998 & 45,45 \\
\hline 2002 & 44,3 \\
\hline 2006 & 45,99 \\
\hline
\end{tabular}

Źródło: Opracowanie własne na podstawie wyników podanych przez Państwową Komisję Wyborczą.

Jak wynika z podanych danych w ostatniej elekcji samorządowej zanotowano w kraju najwyższą frekwencję od czasu pierwszych wyborów samorządowych w 1990 r. (wówczas wynosiła ona 42,27\%, a w 2006 r. 45,99\%). Przewyższyła ona frekwencję w czasie wyborów do Sejmu w 2005 r. (40,57\%). Było to tym bardziej zadziwiające, gdyż do tej pory więcej osób głosowało w wyborach do sejmu niż w następujących po nich wyborach samorządowych. Najniższa frekwencja była w województwie opolskim i śląskim, nie przekroczyła ona 40 proc. $^{7} \mathrm{~W}$ gminach liczących do 20 tys. mieszkańców zanotowano najwyższą frekwencję, bo $50,07 \%$, a w tych powyżej 20 tys. - 44,8\%. Tutaj głosowania nie przeprowadzono w jednym okręgu wyborczym, w którym liczba zarejestrowanych kandydatów była równa liczbie radnych wybieranych w tym okręgu. W związku z tym pięciu radnych uzyskało mandaty bez głosowania. W miastach na prawach powiatu wybrano 64 rady miejskie w 289 okręgach. Fre-

\footnotetext{
${ }^{7}$ Zob. Frekwencja w województwach, „Gazeta Wyborcza”, 14.10.2006 r.
} 
kwencja wyniosła 39,95\%. Wyższą odnotowano do rad powiatowych - 48,03\%, a do 16 sejmików wojewódzkich $45,91 \%{ }^{8}$. Podobnie jak w poprzednich elekcjach, tak i w tej można było wskazać znaczące różnice w jej poziomie w zależności od danego szczebla samorządu. Po raz kolejny najwięcej osób udało się do urn w miastach do 20 tys. mieszkańców.

W takiej dużej aglomeracji jak Łódź, frekwencja w wyborach w 2006 r. wynosiła 36,37\% i była wyższa niż w 2002 r., gdzie do urn poszło zaledwie $25,81 \%$, ale niższa niż ta z 1998 r., gdyż wówczas wyniosła $37 \%{ }^{9}$. Kiedy w kraju do urn w wyborach samorządowych 19 czerwca 1994 r. poszło 33,78\% uprawnionych (9 329776 obywateli), w Łodzi frekwencja była jeszcze niższa i wynosiła $24,68 \%$. Podobnie było podczas pierwszej elekcji samorządowej, gdzie w kraju wynosiła ona 42,3\%, a w województwie łódzkim 34,79 proc.

W 2002 r. odnotowano w kraju nieco niższą frekwencję wyborczą niż w 1998 r. Do rad gmin wynosiła ona 44,3\%. Podobnie jak w poprzedniej elekcji, tak i teraz zanotowano znaczące różnice w jej poziomie w zależności od danego szczebla samorządu. W wyborach do rad gmin liczących do 20 tys. mieszkańców do urn udało się 52,58\% uprawnionych, a w tych powyżej 20 tys. $43,85 \%$. W elekcjach do rad miejskich w miastach na prawach powiatu wynosiła ona 33,24\%, a do rad powiatów 49,48\%. W wyborach do Sejmików Wojewódzkich wzięło udział 44,23\%. Należy także zaznaczyć, iż zanotowano istotnie niższą frekwencję w drugiej turze wyborów wójtów, burmistrzów i prezydentów, bo zaledwie 35\%. Wprowadzenie bezpośrednich wyborów gospodarzy wsi i miast nie spowodowało większej aktywności ze strony wyborców. W tych wyborach po raz pierwszy wybierano 2478 wójtów, burmistrzów i prezydentów miast. O każde z wymienionych stanowisk ubiegało się ponad 4 kandydatów. W pierwszej turze obsadzone zostały 1273 fotele, a więc ponad 51\% wszystkich, a w drugiej pozostałe 1202. Natomiast w trzech miastach, w których żaden z kandydatów nie uzyskał wymaganej większości głosów, wyboru wójta w późniejszym czasie dokonały nowo wybrane rady tych gmin ${ }^{10}$.

Natomiast jak wynika z wyżej przedstawionej tabeli wybory przeprowadzone 11 października 1998 r. spotkały się z większym zainteresowaniem niż te odbyte cztery lata wcześniej. Frekwencja do rad gmin wynosiła 45,45\% uprawnionych do głosowania. Zanotowano także różnice $\mathrm{w}$ jej poziomie w zależności od rozpatrywanego szczebla samorządowego. W małych gminach liczących do 20000 mieszkańców była ona większa i wynosiła 49,51\%, a w tych powyżej 20000 mieszkańców 45,53\%. W wyborach powiatowych wzięło udział $47,76 \%$, a do sejmików wojewódzkich $45,35 \%$ uprawnionych. Najniższą frekwencję odnotowano w miastach na prawach powiatu, gdzie do urn poszło $39,84 \%{ }^{11}$. Należy podkreślić, iż w elekcjach w 1990 i 1994 r. głosowano tylko w gminach, gdyż reformę samorządową, polegającą na utworzeniu dwóch wyższych szczebli jednostek samorządu terytorialnego, a mianowicie powiatu oraz województwa, przy całkowitej zmianie kształtu terytorialnego województwa wprowadzono dopiero w 1998 r. $^{12}$

\footnotetext{
${ }^{8}$ Serwis Samorządowy PAP SA, Kto do rady, 16.11. 2006 r.

${ }^{9}$ Zupa jeszcze nie gotowa, „Wiadomości Dnia” z 14 października $1998 \mathrm{r}$

${ }^{10}$ Dane na podstawie Obwieszczenia Państwowej Komisji Wyborczej z dnia 8 listopada 2002 r. w sprawie zbiorczych wyników wyborów do rad na obszarze kraju, przeprowadzonych w dniu 27 października 2002 r. (Dz. U. 2002, Nr 187, poz. 1568); Obwieszczenie PKW z dnia 11 listopada 2002 r. w sprawie wyników wyborów wójtów, burmistrzów i prezydentów miast przeprowadzonych na obszarze kraju w dniu 27 października 2002 r. oraz w dniu 10 listopada 2002 r. (Dz. U. 2002, Nr 190, poz. 1593).

${ }^{11}$ Zob. Obwieszczenie Państwowej Komisji Wyborczej z dnia 23 października 1998 r. (Dz. U. 1998, Nr 131, poz. 861).

${ }^{12}$ Reforma została wprowadzona ustawą z dnia 5 czerwca 1998 r. o samorządzie powiatowym, t.j. z 2001 r., Dz. U. Nr 142, poz. 1592 z późn. zm. oraz z dnia 5 czerwca 1998 r., t.j. z 2001 r., Dz. U. Nr 142, poz. 1593.
} 
Przyczyny niskiej frekwencji należy upatrywać m.in. w formie sprzeciwu obywateli w stosunku do dokonujących się zmian. Począwszy od okresu transformacji ustrojowej, jaka dokonała się w Polsce po 1989 r. udział w pierwszych demokratycznych wyborach samorządowych był dla wyborców aktem moralnego poparcia dla zmian. Pierwsze całkowicie wolne i demokratyczne wybory charakteryzowały się emocjonalnym napięciem oraz silnymi oczekiwaniami. Partie i komitety nie różnicowały oferty dokonując segmentacji elektoratu, wypowiadały się w imieniu całego „skrzywdzonego” społeczeństwa. Podziały polityczne z okresu kampanii były słabo odzwierciedlone w świadomości społecznej. W dużym stopniu nastapiło przeniesienie preferencji z okresu wyborów parlamentarnych z $1989 \mathrm{r}$.

Dzień przed wyborami samorządowymi jeden z sondaży przeprowadzony 24 i 25 maja 1990 r. w Łodzi wskazywał, że frekwencja w wyborach będzie niewielka, zaś wiele osób spośród tych, które zdecydowały się pójść w niedzielę do lokali wyborczych, nie wiedziało jeszcze, na których kandydatów odda swój głos. Zadziwiające były wyniki sondy przeprowadzonej na osiedlu akademickim na Lumumbowie. Wzięło w niej udział 368 studentów Uniwersytetu Łódzkiego i Akademii Medycznej. 251 osób odpowiedziało, że nie weźmie udziału w wyborach, 103 pójdzie do urn, a 14 było jeszcze niezdecydowanych. Ze 117 osób, które na pewno pójdą na wybory i tych czekających z decyzją do niedzieli - 72 wiedziały jak należy kreślić karty wyborcze, 45 osób nie wiedziało, na czym polega technika głosowania. 69 studentów powiedziało, że będzie głosować na Solidarność. Nie potrafili jednak odpowiedzieć, który z Komitetów Obywatelskich ostatecznie wybiorą. Te wyniki mogą świadczyć o niskim zaangażowaniu młodych ludzi w pierwsze demokratyczne wybory samorządowe. Nie mieli pojęcia o komitetach biorących w nich udział, nie przejawiali zainteresowania samym sposobem głosowania $^{13}$. Wynika $\mathrm{z}$ tego, iż pokolenie 20 -latków nie chciało angażować się w politykę i w same wybory, a jego świadomość reguł demokracji była niewielka.

Podkreślano, że te pierwsze demokratyczne wybory do samorządu miały być zrywem obywatelskim, wynikającym z zachłyśnięcia się wolnością. Badania socjologiczne przeprowadzone w obwodzie wyborczym na Bałutach - jednej z łódzkich dzielnic, dotyczące udziału mieszkańców tego okręgu w ówczesnych wyborach wykazały, iż spośród 2182 osób uprawnionych do głosowania zaledwie $572(26,2 \%)$ wzięło w nim udział, zaś głosów ważnych oddano 530 (24,3\%). Spośród 572 głosujących większość, bo 292 osoby (51\%) stanowili wyborcy, którzy ukończyli 65 rok życia, 414 wyborców $(72,4 \%)$ ukończyło pięćdziesiątkę, zaś młodzież w wieku 18-35 lat reprezentowały przy urnie 62 osoby, co stanowiło 10,8\% głosujących. Z uprawnionych do głosowania 814 osób w wieku 18-35 lat wzięło w nim udział zaledwie $7,6 \%$ tej liczby. Z badań wynika, iż młodzież oraz osoby aktywne zawodowo i społecznie, w średnim wieku zignorowały wybory, a do urn poszli starsi, jak sugerowano, bez głębszej świadomości popierania jakiejkolwiek grupy politycznej, a po prostu z przyzwyczajenia. Potwierdziły się więc wcześniejsze prognozy, iż młodzi ludzie nie byli zainteresowani pierwszymi w pełni demokratycznymi wyborami do samorządu.

Natomiast kolejne wybory samorządowe były dla wyborców już nieco mniej atrakcyjne, gdyż nie chodziło już w nich o zryw narodowy, tylko o zaakcentowanie swoich preferencji politycznych. Dezaprobata w stosunku do nowych władz, które nie do końca radziły sobie z trudnościami ekonomicznymi w regionach, pogłębiającym się bezrobociem, spowodowały, iż obywatele mniej licznie poszli do urn wyborczych w 1994 r. W Łodzi centroprawicowe władze nie mogły poradzić sobie z coraz bardziej narastającym bezrobociem. W wojewódz-

${ }^{13}$ Ilu łodzian pójdzie do urn?, „Gazeta Łódzka” 1990, nr 38, s. 1. 
twie łódzkim w 1991 r. zarejestrowanych w biurach pracy było 87,2 tys. bezrobotnych, a w kwietniu 1994 r. było ich już 110,8 tys. (w tym kobiet 52 tys.). Szczególnie trudno było o pracę w samej Łodzi. W 1991 r. utrzymywał się spadek produkcji przemysłowej. W porównaniu z 1990 r. wyniósł on 18,6 proc (w Polsce - 14,2 proc), mimo że spółdzielnie oddały o 5\% mieszkań więcej niż w 1990 r. to spadła liczba mieszkań w budowie o 23 proc. ${ }^{14}$ Czynniki te złożyły się na negatywny stosunek obywateli do pierwszej demokratycznie wybranej władzy samorządowej. Przejawiło się to w małej aktywności wyborczej w elekcji w 1994 r., która w porównaniu z pierwszymi wyborami była o $8,5 \%$ niższa.

W 1998 r., aktywność obywateli w wyborach samorządowych zwiększyła się w porównaniu z poprzednią elekcją o $11,8 \%$ gdyż część wyborców zrozumiała, iż może mieć wpływ, w wyniku aktu głosowania, na wymianę elit rządzących we władzach lokalnych. Niewątpliwie przyczyniła się do tego wprowadzona w 1998 r. reforma samorządowa polegająca na utworzeniu dwóch wyższych szczebli jednostek samorządu terytorialnego. Z pewnością spowodowała ona większe zainteresowanie wyborami obywateli w nowopowstałych samorządach, o czym świadczy wyższa frekwencja wyborcza niż w elekcji w 1994 r.

Należy zgodzić się z badaczami, którzy zwracają uwagę, iż miejsce zamieszkania wpływa na aktywność wyborczą obywateli. Jak wynika z wyżej przedstawionych danych do urn wyborczych chętniej chodzili mieszkańcy małych gmin liczących do 20000 mieszkańców. Warto więc zaznaczyć, iż stopień ,jawności” udziału w wyborach w małych ośrodkach jest zdecydowanie wyższy. Poza tym w gminach do 20000 mieszkańców wybory przeprowadzane są według formuły większościowej, a jak wynika z badań, obywatele częściej popierają większościowy system wyborczy, bardziej przejrzysty dla nich niż proporcjonalny ${ }^{15}$. Do niewątpliwych zalet zalicza się jego prostotę w wariancie większości względnej oraz oddanie głosu na osobę, a nie na partię polityczną ${ }^{16}$. Należy jednak zauważyć, iż wpływ poszczególnych systemów wyborczych jest zależny od kultury politycznej, charakteru systemu partyjnego oraz kontekstu społeczno-gospodarczego w danym kraju ${ }^{17}$.

Giovanni Sartori określił system wyborczy jako najbardziej specyficzny, manipulacyjny instrument kształtowania polityki ${ }^{18}$. W myśl tego stwierdzenia partie polityczne $\mathrm{w}$ zależności od oczekiwanych korzyści są zwolennikami formuły większościowej, proporcjonalnej albo mieszanej. Kształt systemu wyborczego jest więc wynikiem gry interesów politycznych. Wprowadzenie określonych regulacji w prawie wyborczym wynika z racjonalnych kalkulacji i oczekiwań liderów partyjnych, liczących na to, że dany system będzie działał dla nich z korzyścią ${ }^{19}$.

Warto także zwrócić uwagę na fakt, iż wyborcy w przedwyborczych sondażach deklarowali większą frekwencję niż ta, która była w rzeczywistości.

\footnotetext{
${ }^{14}$ Kolejny rok,,pod kreskq”, „Dziennik Łódzki” 1992, za: Kronika Rady Miejskiej Łodzi, s. 62 oraz Łódzkie w statystyce, „Wiadomości Dania” 1994.

${ }^{15}$ W grudniu 2000 r. 44\% badanych przez CBOS opowiedziało się za systemem większościowym, zaś $16 \%$ za proporcjonalnym; w kwietniu 2002 r. proporcje te wynosiły odpowiednio 40\% i 19\%, a w sierpniu 2004 - 43\% i 16\%. Zob. CBOS, Wybory większościowe czy proporcjonalne, wrzesień 2004, kom. nr 143.

${ }^{16}$ Wybory w 2007 i 2005 r. w Polsce do senatu są jednak odzwierciedleniem tezy, iż wyborca głosując na osobę, wybiera ją ze względu na partię, jaką reprezentuje - przyp. autora.

${ }^{17}$ A. Heywood, Politologia..., op. cit., s. 296.

18 A. Lijphart, Electoral Systems and Party Systems. A Study of Twenty-Seven Democracies 1945-1990, Oxford 1994, s. 139.

19 A. Żukowski, Kierunki ewolucji polskiego systemu wyborczego a interesy partii politycznych, w: K. Kowalczyk, Ł. Tomczak, Partie i systemy partyjne RP. Stan i perspektywy, Torun 2007, s. 23.
} 
Łódzki Ośrodek Badania Opinii Publicznej i Koniunktur Ekonomicznych przed elekcją samorządową w 2002 r. przebadał 875 osób. Badanie dotyczyło frekwencji wyborczej. 40 procent łodzian deklarowało udział w wyborach prezydenckich w II turze ${ }^{20}$. A wzięło w nich udział zaledwie 24,8 procent uprawnionych do głosowania.

Przed wyborami w $2006 \mathrm{r}$. informowano, iż 57\% ankietowanych przez CBOS zamierzało wziąć udział w wyborach samorządowych, 25\% nie chciało iść do urn 12 listopada, a 18\% nie podjęło jeszcze decyzji w tej sprawie. Z sondażu wynikało, że wyborami samorządowymi, częściej niż innymi, interesują się - i planują w nich uczestniczyć - mieszkańcy wsi (61\%) i dużych aglomeracji miejskich (65\%). Zamiar uczestnictwa w głosowaniu deklarowali częściej mężczyźni niż kobiety; najczęściej osoby w wieku 45-64 lat, a najrzadziej najmłodsi ankietowani (do 24 roku życia). Do urn wybierało się 68\% zwolenników lewicy i 69\% osób popierających prawicę. Z badania wynikało także, iż co trzeci (33\%) ankietowany deklarował, że będzie uczestniczył w wyborach i ma już kandydata, na którego chce głosować w wyborach do rady miasta (gminy). 45\% wiedziało, na jaki komitet zagłosuje, a nie wybrało jeszcze kandydata. Ponad jedna piąta (22\%) nie miała jeszcze żadnych preferencji, co do wyboru radnych. Wśród mieszkańców miast liczących ponad 500 tys. mieszkańców $35 \%$ miało sprecyzowane preferencje wyborcze ${ }^{21}$. Jedna $\mathrm{z}$ łódzkich gazet zapytała 100 przypadkowych osób, czy zamierzają głosować w wyborach samorządowych, w których będą wybierać prezydenta i radnych. Ponad połowa (58 osób) powiedziała, że na wybory nie pójdzie, a 38 zadeklarowało chęć uczestnictwa w wyborach, traktując to jako obywatelską powinność, a czterech jeszcze nie wiedziało ${ }^{22}$. Wyniki te obrazowały podmiotom politycznym, na jaką frekwencję mogą w przybliżeniu liczyć. W rzeczywistości uległa ona pomniejszeniu, gdyż do wyborów w 2006 r. poszło zaledwie 36,37\% łodzian.

Reasumując, należy stwierdzić, iż w wyborach samorządowych mamy do czynienia z dwoma rodzajami nieobecności: zawinioną oraz przymusową ${ }^{23}$. Ten pierwszy odnosi się do wyborcy, który świadomie rezygnuje z udziału w głosowaniu. Może to być wynikiem braku zainteresowania polityką, brakiem zaufania do polityków lub brakiem alternatywy wyborczej czy niskim poczuciem podmiotowości obywatelskiej. Nieobecność zawinioną możemy zaobserwować u ludzi młodych. Jak zauważa prof. J. Czapiński, w Polsce nieuczestniczenie w wyborach ludzi młodych wynika z niedostrzegania przez nich wpływu polityki na codzienne życie. Dla nich ważna jest praca, rodzina, studia, a nie to czy w Polsce będzie dyktatura czy demokracja. Dominuje postawa, że obojętnie, jak będzie, oni musza jakoś dać sobie radę. Sami. Nie do końca rozumieja przełożenie polityki wewnętrznej na własne perspektywy ${ }^{24}$. Nieobecność zawiniona występuje także wśród obywateli, którzy zawiedli się na nowej władzy. Ich oczekiwania w stosunku do rządzących były znacznie wyższe niż szybkość zachodzących przemian $\mathrm{w}$ regionie. $\mathrm{Z}$ taką sytuacją mieliśmy do czynienia podczas drugiej elekcji samorządowej, gdzie do urn wyborczych poszło znacznie mniej obywateli niż wcześniej deklarowało. Transformacja ustrojowa była przez nich postrzegana negatywne, gdyż mieli problemy z odnalezieniem się w nowej rzeczywistości. Absencja zawiniona może być

\footnotetext{
${ }^{20}$ Jagiełto - 56 procent, ,Gazeta Łódzka”, 7 listopada 2002.

${ }^{21}$ Badanie zrealizowano w dniach 6-9 października na liczącej 999 osób reprezentacyjnej próbie losowej dorosłych mieszkańców Polski. Zob. Serwis Samorządowy PAP SA//WWW.samorząd.pap.pl.

${ }^{22}$ Czy todzianie pójdq na wybory?, „Express Ilustrowany”, 18.10.2006.

${ }^{23}$ Aktywny obywatel, nowoczesny system wyborczy, red. L. Kolarska-Bobińska, Warszawa 2006, s. 16.

${ }^{24}$ Poradzq sobie i bez polityków - rozmowa A. Więcki z prof. J. Czapińskim, Rzeczpospolita” z 29-30 października 2005 r.
} 
także wynikam zaniedbania w zakresie edukacji na temat wiedzy o samorządzie lokalnym W znaczeniu sensu largo. W szkołach nadal zbyt mało miejsca poświęca się wychowaniu obywatelskiemu w aspekcie społeczności lokalnej. Także media koncentrują się niemal wyłącznie na pracach parlamentu, całkowicie pomijając wagę dla społeczeństwa władzy samorządowej. Przeciętny obywatel wspólnoty lokalnej zna bardziej posłów niż samorządowców wybieranych z jego macierzystego rejonu. Mieszkańcom bowiem brakuje wiedzy na temat obowiązków realizowanych przez samorządy lokalne, które od 1990 r. przejęły na siebie ponad $2 / 3$ zadań publicznych.

Nieobecność przymusowa charakteryzuje wyborcę pragnącego oddać swój głos, ale z przyczyn od niego niezależnych nie mogącego wziąć udziału w głosowaniu. Do osób tych należą najczęściej osoby schorowane, niepełnosprawne, mające ograniczony zakres poruszania się, a tym samym dotarcia do lokalu wyborczego. Dla tych wyborców warto wprowadzić nowoczesne formy głosowania, chociażby przez pełnomocnika, głosowanie korespondencyjne czy przez Internet. Obowiązujące obecnie w Polsce procedury głosowania należy uznać za najbardziej konserwatywne w Europie ${ }^{25}$.

Czy tendencja wzrostowa, co prawda niewielka, jaką zanotowano w wyborach samorządowych w 2006 r. jest tylko chwilowa, czy może jest to zapowiedź bardziej znaczącego zaangażowania obywateli w mechanizm egzekwowania większej odpowiedzialności politycznej od elit na szczeblu lokalnym? Aby tak się stało potrzebne jest większe zaangażowanie mediów, nauczycieli i samych zainteresowanych w uzyskiwaniu i przekazywaniu wiedzy na temat roli i zadań samorządów lokalnych.

Po wprowadzeniu w 2002 r. powszechnych wyborów prezydentów miast, wójtów i burmistrzów, wybrany demokratycznie prezydent, chcąc mieć poparcie większości ciała stanowiącego, jakim w dużych miastach w Polsce jest Rada Miejska, buduje w niej swoje zaplecze polityczne w postaci obsadzenia na stanowiskach swoich zastępców kandydatów z formacji mu pokrewnych. Ponoszą oni całą odpowiedzialność za rządzenie miastem przez czteroletnią kadencję. Kolejne wybory są dla nich niewątpliwie sprawdzianem i oceną ich rządów. Wydają ją lokalni wyborcy, którzy mogą przedłużyć mandat zaufania dotychczasowym formacjom politycznym władającym miastem lub go wycofać i powierzyć rządzenie opozycji. Wybory dają więc rządowi i społeczeństwu, elitom i masom możliwość wpływania na siebie nawzajem ${ }^{26}$.

\section{Summary}

The focal point of this paper is voter turnout in the self-government elections in Poland. Particular attention is given to the turnout in the city with district rights, Łódź. This city provides an interesting place of research, both on account of its peculiar location in the center of Poland, and its recent cultural, economic and political transformation. A local referendum on the dismissal of the city mayor, held on January 10, 2010, is worth mentioning. Łódź was the

\footnotetext{
${ }^{25} \mathrm{O}$ istocie głosowania elektronicznego oraz pracach nad jego stosowaniem w krajach europejskich pisze obszernie K. W. Czaplicki, Głosowanie elektroniczne (e-voting) - wybrane zagadnienia, w: Demokratyczne standardy prawa wyborczego Rzeczypospolitej Polskiej. Teoria i praktyka, Warszawa 2005.

${ }^{26}$ A. Heywood, Politologia, op. cit., s. 286.
} 
first large Polish city (with a population of over 500,000) where a one-man executive organ was dismissed before the end of his term.

In the paper, the results of parliamentary election turnouts are juxtaposed with self-government election turnouts. Voter turnout is analyzed for each term of the self-government in Łódź, and the types and reasons for absence are indicated. The author uses these data to emphasize that over the twenty years of self-government's existence, voting procedures in Poland have not changed and are the most conservative in Europe. 